\title{
Ulus Devlet Oluşturmada Yunanistan Örneği: Büyük Ülkü-Megali İdea
}

\section{Outkou KIRLI NTOKME*}

\section{$\ddot{O z e t}$}

18. yüzyılda Avrupa'da yaşanan siyasal ve ekonomik devrimlerin Osmanlı idaresi altında yaşayan Yunan toplumuna yansiması, ticaret yollarının Imparatorluğun Yunan nüfusunun yoğun olarak yaşadığı bölgelerde (Anadolu'nun Ege kıyıları, Balkanlar, Moldavya) gelişmesi sonucunda oldu. Avrupa'ya eğitim için giden Yunanl gençler ve tüccarlar Aydınlanma fikirlerini ve milliyetçilik ideolojisini benimseyerek, bunların Yunan toplumuna aktarlmasina katkida bulundular. Avrupa'daki gelişmelerin belli bir gecikme ile benimsenmesinin ardindan Yunan Aydınlanması ile başlayan hareket, dönemin uluslararası zemininin de müsait olmasıla birlikte, 1821'de Mora Yarımadası'nda başlayan Yunan Ayaklanması, 1830'da dönemin Büyük Devletleri'nin kontrolü altında olan ve bir monarşik rejimle yönetilmesi kararlaştırılan bağımsız bir devlet olarak sonuçlandı.

Böylelikle, ulusal devlet ve ulusal kimlik yaratma projesi çerçevesinde 1833 'te Yunanistan Ortodoks Kilisesi; aynı bağlamda devletin idari yapısındaki ihtiyaçları karşılamak üzere gerekli personeli eğitmek ve Doğu’ya Batı medeniyetinin taşınmasını sağlamak amacıyla 1837'de Atina Üniversitesi kuruldu. Tarihin Helenleştirilmesi çerçevesinde Yunan ulusunun Bizans geçmişiyle barış sağlandl. Öte yandan Helenizm 'in tarih boyunca sürekliliğinin sağlanmast ile birlikte Megali İdea da resmiyet kazandı. Büyük Yunanistan'ın kurulması hayalinin açık bir ifadesi olarak Yunan ulusunun varoluş sebebi oldu. Fakat Türk Kurtuluş Savaşı sonucunda

* Ankara Üniversitesi Siyasal Bilgiler Fakültesi Uluslararası İlişkiler Doktora Öğrencisi, TÜBİTAK-2215 Yabancı Uyruklular İçin Doktora Burs Programı'ndan yararlanmaktadır. 
(1922) Megali İdea Yunan resmi dış politikasından çıkmasına ră̆men, Yunan ulusunu bir arada tutmak için akıllarda daima yer alan ve gerçekleşmesi arzulanan bir olgu olarak kaldl.

Anahtar Kelimeler: Yunanistan, Tarih, Yunan siyaseti, Megali İdea.

\title{
The Greek Example of Creating Nation State: Megali Idea
}

\begin{abstract}
The reflection of the political and economical revolutions which took place in Europe in the $18^{\text {th }}$ century, to the Greek society living under the Ottoman rule was realized through the development of channels of commerce at the regions of the Empire (such as the Aegean shores of Anatolia, Balkans, Moldavia) where mainly the Greek population lived. Young Greeks by going for education to Europe and merchants by going to Europe adopted the ideas of the Enlightenment and the ideology of nationalism. Thus they made a contribution to the transfer of these ideas and ideology to the Greek society. While the developments of Europe were adopted with some delay, the movement that began with the Greek Enlightenment and with the available international circumstances, the Greek upheaval which started in 1821 at the Peloponnese peninsula resulted with the creation of an independent monarchical Greek state under the control of the Great Powers of the period.

In this way, under the project of creating a nation state and a national identity, in 1833 the Greek Orthodox Church was established. Likewise, in 1837 the University of Athens was founded for the education of the necessary personnel in order to meet the administrative needs of the state and to convey the Western civilization to the East. Also by Hellenizing History, peace with the Byzantine past was made. On the other hand, trough securing historical continuity of Hellenism, Megali Idea gained formality. In plain terms the vision of creating a Great Greece, became a basis of existence of the Greek nation. But despite the fact that Megali Idea was detached formally from the Greek foreign policy with the end of the Turkish War of Independence (1922), it has remained always in the minds as a wish to be realized in order to keep the Greek nation together.
\end{abstract}

“Key words:" Greece, History, Greek politics, Megali Idea.

\section{GíRiş}

Aydınlanma dönemi ile birlikte Avrupa'da gerçekleşen devrimlerin etkileri farklı ülkelerde, farklı zamanlarda ve farklı şekillerde hissedilmiştir. 
Ayrıca devrimler, çeşitli kültürel ortamlarda farklı şekillendiklerinden dolayı biçim açısından da farklılık göstermişlerdir. Bu farklılıkların yansıması ulusların oluşum sürecinde de etkili olmuştur. Örneğin Fransız Devrimi sonucunda siyasi alanda güçlü bir ideolojik akım olarak yerini alan ve günümüzde de halen güçlü olan milliyetçilik, 19. yüzyıl itibarıyla birçok ulus için ulus-devlet olma mücadelesinin itici bir gücü olmuştur.

Çağımızda milliyetçilik gerek bir ideoloji gerekse bir yaklaşım olarak tarih ve sosyal bilimlerin çeşitli alanlarında araştırma konusudur. Aynı zamanda milliyetçilik, Avrupa'da gerçekleşen Aydınlanma süreci gibi, farklı toplum ve ülkelerde, farklı zamanlarda ve farklı şartlar altında farklı biçimler alması hasebiyle tanımında fikir birliği sağlanmamış bir olgu halini almıştır. ${ }^{1}$ Milliyetçilik, ilk başta toplumsal özgürlük ve egemenlik doktriniydi. Buna göre insanlar özgürleştirilmeli, tüm dış baskılardan kurtarılmalı, kendi kaynaklarını ve topraklarını kendileri kontrol etmeli, kendi kaderlerini kendileri tayin etmeli ve sadece kendi içlerindeki sese kulak vermeliydiler. "Insanlar birlik olmalı, tüm iç bölünmeler ortadan kalkmall, tarihi bă̆lllı̆̆ olan tek bir toprak parçası üzerinde birlik içinde yaşamalı ve ortak bir kültürü paylaşmalıydılar".2

Etnik bir topluluğun hangi aşamada ulus olma yolunda geliştiğini tam olarak açıklayamasak da, Avrupa'da 18. yüzyıldan 19. yüzyıla uzanan devrimlerin etkisi olduğunu söyleyebiliriz. Emeğin iş bölümü alanındaki devrim (feodalizmden kapitalizme geçiş ile kültür ve eğitim alanındaki devrim), kilise kontrolü dışında oluşan rasyonel devlet yapısı ve bilimde laik çalışmalar sonucunda toplumlarda ulus olma bilincinin şekillendiğini görmekteyiz. Modernist teorinin temsilcilerinden Benedict Anderson,

\footnotetext{
${ }^{1}$ Milliyetçiliğin farklı yerlerde ve farklı şartlarda ortaya çıkmasına ilişkin olarak Baskın Oran şöyle demektedir: "Millet öğesinin var olduğu, fakat ulusal devletin bulunmadığı İtalya ve Almanya örneklerinde bir birleştirme hareketi oldu. Oysa milliyetçilik, koşullar gerektiğinde mevcut siyasal birimden kopup yeni bir devlet kurarak ayrılma hareketi de olacaktı (Polonyalılar, Ukraynalılar, Çekler, Slovaklar, Finler, Yunanlılar, Bulgarlar). Gene milliyetçilik terimi bir yandan İtalyan irredantizmi, Sırp ve Romen örneklerinde kardeşliği anlatmak için kullanılırken, bütün Avrupa halklarını düşman etmek için başvurulan ve sömürülen 1 numaralı kavram oldu. Aynı kavram statükoyu koruma (Avusturya-Macaristan, Rusya, Alman İmparatorlukları), sömürgecilik (İngiltere, Fransa, Portekiz) ve iktisadi yayılma (ABD) anlamlarına gelebiliyordu. Milliyetçilik Nazi Almanya'sında, Faşist İtalya'da, Militarist Japonya'da emperyalist saldırıya arka çıkmıştı. Oysa 20. yüzyılın ikinci yarısında az gelişmiş ülkelerde antiemperyalizmle eş anlama gelmeye başladı”. Bkz. Baskın Oran, Azgelişmiş Ülke Milliyetçiliği, Güncelleştirilmiş 3. Bask1, Bilgi Yayınları, Ankara, 1997, s. 21-22.

${ }^{2}$ John Hutchinson ve Anhony D. Smith (der.), Nationalism, Oxford University Press, Oxford ve New York, 1994, s. 7.
} 
kapitalizme geçilirken yaşanan iktisadi değişimin halk dillerinin yaygınlaşmasındaki etkilerine değinerek, matbaanın ve yayıncılığın ulusal bilincin gelişmesine katkıda bulunduğunu ifade etmektedir. ${ }^{3} 18$. yy.'a kadar Avrupa'nın entelektüelleri tarafından kullanılan Latince zamanla değişime uğramış, farklı bir nitelik kazanmış ve 17. yy. itibarıyla Avrupa dilleri modern şekillerini almışlardır. ${ }^{4}$ Kilisede Reform Savaşları döneminde başlayan süreç ile yayıncılık gelişmiş ve Avrupa'da zamanla artan bir okur kitlesi oluşmuştur. Ayrıca halk dilleri gelişerek idari merkezileşmenin aracı olarak kullanılmaya başlanmıştır. ${ }^{5}$ Böylece, halk ile idarecilerin konuştuğu dil aynılaşmış, halk dillerinin yaygınlaşması sayesinde halk ile yöneticiler arasında sağlanan dilsel birliktelik ulus fikrinin ortaya çıkmasına katkıda bulunmuştur. Anderson aynı zamanda etniseden daha kapsamlı bir kavram olan ulusun üzerinde durarak, ulusun hayal edilmiş siyasal bir topluluk ve hem egemen hem de sınırlı olacak şekilde hayal edilmiş bir cemaat olduğunu söylemektedir. ${ }^{6}$

Balkan yarımadasında yer alan ve üç tarafı denizle çevrili bir ülke olan Yunanistan, bölgede modern devlet yapısına sahip ilk ülkelerden bir tanesidir. Ekonomik açıdan sanayileşme düzeyi düşük olan ülkenin en büyük gelir kaynağı hizmet sektörüdür. Yunan devleti ve Yunanlılar zengin tarih geçmişi ve kültürü ile övünmektedir. Ülkede hemen hemen her alanda geçmiş ve Yunan tarihine sürekli atıf yapılmaktadır. Yunan ulusal kimliğinin oluşum süreci Yunanistan'ın bağımsız bir devlet olma mücadelesiyle başlamış, bugüne kadar çeşitli evrelerden geçerek devam etmiştir. Yunanistan'da yaşanan her iç ve dıș politika gelișmesinin Yunan ulusunun kimliği üzerinde etkisi olmuş, onu şekillendirmiştir.

18. yüzyılda Avrupa'da yaşanan siyasal ve ekonomik devrimlerin Osmanlı idaresi altında yaşayan Yunan toplumuna yansıması, ticaret yollarının İmparatorluğun Yunan nüfusunun yoğun olarak yaşadığ bölgelerde (Anadolu'nun Ege kıyıları, Balkanlar, Moldavya) gelişmesi sonucunda oldu. Yeni ticaret merkezleri haline gelen bu bölgelerin yanı sira, Rusya'da yaşayan Yunanlılar arasında da zamanla tüccar ve esnaflardan oluşan yeni bir sosyal sınıf ortaya çıktı. Bu sınıfın Yunan toplumunun sosyal

\footnotetext{
${ }^{3}$ Benedict Anderson, Hayali Cemaatler; Milliyetçiliğin Kökenleri ve Yayılması, çev. İskender Savaşır, 2. Bask1, Metis, İstanbul, 1995, s. 54.

4 Monserrat Guibernau, Nationalism; The Nation State and Nationalism in Twentieth Century, Polity Press, Cambridge, 1996, s. 66.

${ }^{5}$ Anderson, a.g.e., s. 56.

${ }^{6}$ Anderson, a.g.e., s. 56; Kellas ise, ulus fikrinin Antik Çağ’a kadar uzandığına inanmakta ve bütün ulusların olmasa bile, en azından Yunanlıların ve Yahudilerin bu şekilde kabul edilebileceğini ileri sürmektedir, bkz., James G. Kellas, The Politics of Nationalism and Ethnicity, MacMillan, Londra, 1991, s. 20-22.
} 
gelişimine katkısı çoğunun çocuklarının mesleki eğitim almak üzere Batı’ya gitmesiyle başladı. Avrupa'ya eğitim için giden gençler ve tüccarlar Aydınlanma fikirlerini ve milliyetçilik ideolojisini benimseyerek, bunların Yunan toplumuna aktarılmasina katkida bulundular. Ayrica Osmanlı İmparatorluğu içinde ve dışında yaşayan Yunanlıların bulundukları bölgelerde çeşitli vakıf okulları ve kütüphaneler kurulmaya başlandı. ${ }^{7}$

Aydınlanma ile Fransız Devrimi'nin romantik milliyetçiliğinin önemli görüşleriyle tanışan Yunanlı gençler, Avrupalılar gibi Antik Helen'i yeniden keşfettiler. ${ }^{8}$ Böylelikle Yunan Aydınlanması $1{ }^{9}$ 18. yüzyılın sonlarına doğru Avrupa'daki gelişmelerden etkilenen Yunanlı aydın sınıfının oluşumuyla gelişmiş ve Yunanca, Aydınlanma değerlerinin Balkanlarda sadece Yunanlılara değil, diğer Ortodoks toplumlara aktarılmasında da aracı dil halini almıştır. ${ }^{10}$

Yunan Aydınlanması, Millas'ın belirttiği gibi “Batı dünyasına açık Yunanlılar" arasında temelde Avrupa'daki gelişmelerin belli bir gecikme ile benimsenmesidir. ${ }^{11}$ Aydınlanma sürecindeki Avrupa'nın antik Yunan'a hayranlığını gören Yunanlı aydınlar, büyük medeniyet olarak tanımlanan antik Yunana sahip çıkarak etnik kökenlerini ${ }^{12}$ vurgulamaya ve Osmanlı hâkimiyetinden kurtularak yeni bir devlet çatısı altında toplanmak için bağımsızlık fikirlerini halka ve Avrupa'ya duyurmaya çalıştılar. ${ }^{13}$ Aydınlara göre, bu amaca ulaşmak için yeni bir kimliğin (Çağdaş Yunan kimliği) benimsenmesi gerekmekteydi. Çağdaş Yunan kimliğini benimsemenin yolu ise modern ve laik eğitim ile toplumun çoğunluğunu oluşturan eğitimsiz

${ }^{7}$ Richard Clogg, A Concise History of Greece, 2. Bask1, Cambridge, 2002, s. 25.

8 Alexis Politis, "Christian Emperors to Greek Ancestors", Byzantium and the Modern Greek Identity, David Ricks ve Paul Magdalino (der.), Centre for Hellenic Studies, King's College, Londra, 1998, s. 8.

${ }^{9}$ Yunan Aydınlanması diye bilinen akım 18. yüzyılın ortalarından başlayarak 19. yüzyıl başlarında doruğa ulaşmıştı. Herkül Millas, Yunan Ulusunun Doğuşu, İletişim Yayınları, İstanbul, 1994, s.43. Yunan Aydınlanmasının kapsamlı bir çalışması için bkz., H. Th. Dimaras, Neoellenikos Diafotismos, 7. Bask1, Atina, 1998.

${ }^{10}$ Paschalis M. Kitromilides, "Imagined Communities and the Origins of the National Question in the Balkans", European History Quarterly, Cilt 19, No 2, 1989, s. 151.

${ }^{11}$ Millas, a.g.e., s.46.

${ }^{12}$ Yunanlıların Osmanlı topraklarında yaşayan diğer Hıristiyanlardan farklı bir "etni" olduklarını ilk kez ifade eden Dimitrios Katartzis'dir. Yunan edebiyatına da katkısı olan Katartzis hakkında daha detaylı bilgi için bkz., Dimaras, a.g.e., s. 177-243.

$13 \mathrm{Bu}$ dönemde Avrupa'nın çeşitli kentlerinde (örneğin Paris, Viyana) Yunanlı Aydınların davasına hizmet eden dergiler çıkmıştır. Bkz., Gregory Jusdanis, Gecikmiş Modernlik ve Estetik Kültür Milli Edebiyatın İcat Edilişi, çev. Tuncay Birkan, Metis Yayınları, İstanbul, 1998, s.190-191. 
köylü Yunanlılara, Hıristiyan Bizans dışındaki geçmişlerini öğretmekten geçmekteydi. ${ }^{14}$

Yunan Ayaklanması Mart 1821'de Mora Yarımadasında başladı ve kısa sürede dönemin büyük güçlerinin ilgisini çekmeyi başardı. ${ }^{15} 1815$ Viyana Kongresi'nin sonuçları dikkate alındığında, monarşik Avrupa devletlerinin Yunan ayaklanmasına destek vermesi mümkün değildi. Zira sadece Osmanlı İmparatorluğu değil Avusturya-Macaristan İmparatorluğu da dağılma tehlikesi ile karşı karşıyaydı. Fakat Viyana Kongresi'nin temsil ettiği monarşik tutucu akımın, Fransız Devrimi ile tüm Avrupa'ya yayılmaya başlayan özgürlükçü liberal akımlara direnmesi de çok uzun sürmedi. Özellikle Rusya'da yaşayan Yunanlılar için Rusya kurtarıcı olarak görülmekteydi. Kutsal İttifak devletlerinin Yunan ayaklanmasına müdahalesi ise kendi kamuoylarının Yunanistan'da yaşanan gelişmelere ilişkin tepkisi ve Avrupa çapındaki Helensever komitelerin girişimleri sonucunda başlamıştı.

Bu bağlamda, yukarıda ifade edilen gelișmeler de dikkate alınarak, bu çalışmada 1830-1922 döneminde Yunanistan'in Osmanlı İmparatorluğu'ndan koparak bağımsızlığını elde ettikten sonraki iç siyasi gelişmeleri ele alınacak; dönemin Yunan milliyetçiliğini tanımlayan Büyük Ülkü-Megali İdea'nın ${ }^{16}$ resmi olarak dile getirilişine ve Yunanistan'daki

${ }^{14}$ Politis, a.g.m., s. 3-4.

15 Ayaklanmanın Mora Yarımadasında başlamasının nedeni bölgenin birçok yerinin özerk ve topraklarının çoğunluğunun Yunanlılara ait olmasıdır. Köylülerin başlattığı ayaklanma ilk etapta zenginlere karşı olmuş, daha sonra ulusal bir atmosfer içinde gelişmiştir. Daha detaylı bilgi için bkz., Oral Sander, Siyasi Tarih, Cilt I, 5. B., İmge, Ankara, 1994, s. 128-134.

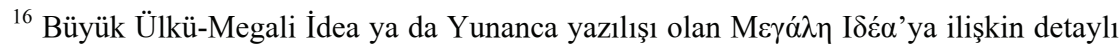
bilgi ve farklı yorumlar için bkz., Eleni Glikatzi-Arveler, İ Politiki İdeologia tis Vizantinis Aftokratorias, 4. Bask1, Psihogios Yayınları, Atina, 1992, s. 123-131; Stathis Gourgouris, Dream Nation, Enlightment, Colonization and the Intsitution of Modern Greece, Standford University Press, California, 1996, s.144-152; Jusdanis, a.g.e., 113-121 ve 170; Elli Skopetea, To Protipo Vasileio kai i Megali İdea, Opseis tou Ethnikou Provlimatos stin Ellada (1830-1880), Politipo Yayınlar1, Atina, 1988, s. 251-347; E. Karathanasis, İ Trisimi Enotita tou Ellinismou, Archaiotita-Byzantio-Neos Ellinismos, Selanik, Kiriakidi Kardeşler Yayınları, Selanik, 1991, s. 41-43; Paschalis M. Kitromilides, "On the intellectual content of Greek nationalism: Paparrigopoulos, Byzantium and the Great Idea”, Byzantium and the Modern Greek Identity, David Ricks ve Paul Magdalino (der.), Centre for Hellenic Studies, King's College, Londra, 1998, s. 25-33; Nikos G. Svoronos, Anelekta Neollinikis İstorias kai İstoriografias, 3. Bask1, Themelio Yayınları, Atina, 1999, s. 286-287; Thanos Veremis, "Kratos kai Ethnos stin Ellada 1821-1912", Ellinismos kai Ellinikotita, 
yansımalarına da değinilerek gelişimi ve yine resmi olarak sona ermesi değerlendirilmeye çalışılacaktır.

\section{Bağımsızlık Sonrası Yunanistan}

Osmanlı İmparatorluğu'na karşı başlatılan ayaklanma, bağımsız bir devlet olma süreci ve bunu takip eden dönemlerde, Yunan milliyetçiliği, Yunan ulusu ve Yunan devleti için daima etkili ve belirleyici bir güç olmuştur. Yunanistan bağımsızlığını Rusya'nın Osmanlı İmparatorluğu'na karşı kazandığ 1 bir zafer sonucunda elde etmiştir. ${ }^{17}$ Rusya'nın Yunanistan aracilığıla bölgede etkin olmasından rahatsız olan İngiltere, Şubat 1830'da Londra'da imzalanan bir protokolle, Yunanistan'ın verasete bağlı bir monarşi ile yönetilmesi ve yeni devletin kralının İngiltere, Fransa veya Rusya’yla doğrudan bağlantılı olmayan bir aileden seçilmesi sağlandı. Böylelikle İngiltere, Edirne Antlaşması'na bağlı kalmaksızın yeni Yunan devletini tanıyarak bölgede Rusya'ya karşı güç dengesini korudu. Londra Protokolü gereğince Yunanistan Krallığı önce Leopold Sakskoburg'a teklif edildi, fakat onun reddetmesi üzerine Bavyera Kralı I. Ludwig'in küçük oğlu Otto'nun Yunanistan Kralı olması kararlaştırıldı. ${ }^{18}$ Dolayısıyla Yunanistan şeklen bağımsız bir devlet olsa da, aslında dönemin Büyük Devletlerinin kontrolü altında monarşik rejimle yönetilen bir devlet oldu. Öte yandan

İdeologikoi kai Viomatikoi Aksones tis Neoellinikis Koinonias, D. G. Tsaousis (der.), Estia Yayınları, Atina, 1983, s. 59-67.

${ }^{17}$ 1828-1829 Osmanlı-Rus Savaşını sona erdiren barıș anlaşması 14 Eylül 1829'da Edirne'de imzalanmıştır. 16 maddelik anlaşmanın 10. Maddesine göre Osmanlı Devleti Yunanistan'ın bağımsızlığını tanıyordu. Bkz., Fahir Armaoğlu, 19. Yüzyıl Siyasi Tarihi (1789-1914), 4. Bask1, Alkım Yayınevi, İstanbul, 2007, s. 183-184.

${ }^{18}$ Büyük devletlerin Yunanistan'ın bağımsızlığına müdahalesi sadece bununla sınırlı kalmamıştır. Bağımsızlığın ardından kurulan ve İngiltere, Fransa ve Rusya'nın çıkarlarını temsil eden siyasi partiler üzerinden etkileri devam etmiştir. Söz konusu partiler sadece yabancı ülkelerin çıkarlarını temsil etmekle kalmamış, isimleri de bağlantılarını yansıtmıştır: İngiliz Partisi, Fransız Partisi, Rus Partisi. Böylece Yunanistan, dönemin Büyük Devletlerinin güç dengesi oyununun sahası olmuş ve bu şekilde oluşturulan dışa bağımlılık uzun yıllar Yunanistan iç siyasetini meşgul etmiştir. Bkz., Nikos G. Svoronos, Episkopisi tis Neoellinikis İstorias, Yunancaya çev. Aikaterini Asdracha, Themelio Yayınları, Atina, 1999, s. 79. M. Fatih Tayfur'un ifade ettiği gibi, Yunanistan'ın bağımsızlığını kazanmasındaki belki de en önemli gelişme "Doğu Akdeniz'e doğru genişleyen yeni ekonomik sistemin" ihtiyaçlarına cevap verebilecek ve bu "sistemi faaliyete geçirecek eğitim ya da deneyime sahip insan kaynağının ya da potansiyelin bulunduğu" bir bölge olmasıdır. Bkz. M. Fatih Tayfur, "Akdeniz'de Bir Adanın Kalın Uçlu Bir Kalemle Yazılmış Hikayesi: Kıbrıs", Akdeniz'de Bir Ada, O. Türel (der.), İmge Yayınları, Ankara, 2002, s. 14-17. 
Yunanistan'ın bağımsızlığını kazanmış olması Osmanlı İmparatorluğu için dağılmanın da başlangıcı olmuştur.

Şubat 1833 'te tahta çıkan Otto reşit olmadığından, ülke 1835 'e kadar kralın eşliğinde gelen Bavyeralı üç kişiden oluşan bir kurul tarafından yönetildi. Kral Otto'nun karşılaştığ en önemli sorunlardan biri devlet altyapısının oluşturulması ile ilgiliydi. Yunan halkı yönetimden memnun olmasa da, bu dönemde düzenli orduya geçildi ve Fransa ile Almanya örneğine uygun eğitim tarzı benimsendi. ${ }^{19}$ Yine de, ayaklanmada yer alan gruplar ve aydınlar dışında ulusçuluk anlayışını benimsemiş olanların sayısının azlığı nedeniyle yeni bir devlet kadar yeni bir ortak kimliğin, yani Çağdaş Yunan kimliğinin yaratılması da gerekmekteydi.

Aydınlanma döneminde Antik Yunan'a duyulan hayranlık Kral Otto döneminde de devam etti. Atina'nın Yunanistan Krallığı'nın başkenti olarak seçilmesi ve binaların neoklasik stilde inşası Skopetea'nın ifade ettiği gibi, "antik dünyanın Krallık içinde organize edilmiş bir ifadesini teşkil ediyordu". ${ }^{26}$ Böylelikle çağdaş Yunanlıların antik Yunanlıların torunları olduğu tezi açıkça benimsenmiş ve etnik kimliğin tarihin içinde sürekliliği sağlanmıştı.

Ulusal devlet ve ulusal kimlik yaratma projesi çerçevesinde 1833 'te Yunanistan Ortodoks Kilisesi, İstanbul Rum Ortodoks Patrikhanesi'nin iznini almadan bağımsızlığını, otosefal olduğunu ilan etti. Yunanistan Ortodoks Kilisesi'nin bu hareketi nedeniyle Yunanistan Ortodoks Kilisesi ile Patrikhane arasındaki ilişkiler 1850'ye kadar kesildi. ${ }^{21}$ Böyle bir politikanın izlenmesindeki amaç Kilise'nin devlet kontrolü altına alınmasını sağlamaktı. ${ }^{22}$ Ayrıca ayaklanma sırasındaki tutumundan dolayı Patrikhane'ye duyulan güvensizlik ${ }^{23}$ devam etmekteydi. Üstelik artık

${ }^{19}$ Clogg, a.g.e., s. 69.

${ }^{20}$ Skopetea, a.g.e., s. 171.

${ }^{21}$ Kitromilides, Imagined Communities and the Origins of the National Question in the Balkans", s. 165.

22 Yannis Stavrakakis, "Religion and Populism: Reflections on the 'politicised' discourse of the Greek Church", Discussion Paper No. 7, The Hellenic Observatory, London School of Economics and Political Science, Londra, 2002, s. 15.

${ }^{23}$ İstanbul Rum Ortodoks Patrikhanesi Osmanlı idari sistemi (millet sistemi) altında Bizans döneminde olduğundan daha fazla otorite sahibi olmuş ve Ortodoks Patriği milletbaşı (Ortodoks toplumunun lideri) olarak kabul edilmiştir. Böylece elde ettiği dini, siyasi ve hukuki imtiyazlar sayesinde Patrikhane, sadece Yunanlılar değil, İmparatorlukta yaşayan tüm Ortodokslar üzerinde kontrol imkânı sağlamış, ruhban sınıfı da aynen Bizans'ta olduğu gibi toplumsal yapı içerisinde etkinliğini korumayı başarmıştır. İstanbul Rum Ortodoks Patrikhanesi’nin millet sistemi altında elde ettiği yetkiler ve çeşitli imtiyazlar için bkz. D. A. Zakythinos, The Making of Modern Greece From Byzantium to Independence, Rowman 
Helenizm'in yeni merkezi Atina'yd ${ }_{1}$ ve ulusal birliğin güçlenmesi için Kilise'nin merkezi de orada olmalıyd. ${ }^{24}$

Ulusal kimliğin ve Helenizm'in güçlenmesi için atılan diğer bir adım da 1837 'de Atina Üniversitesi'nin kurulması oldu. Atina Üniversitesi'nin görevi, devletin idari yapısındaki ihtiyaçları karşılamak üzere gerekli personeli eğitmek ve Doğu'ya Batı medeniyetinin taşınmasını sağlamaktı. ${ }^{25}$ Böylece buradan mezun olan doktor, gazeteci, avukat gibi meslek sahipleri, Osmanlı hakimiyeti altındaki topraklarda yaşayan Yunanlılara Yunanca'y1 ve Yunan kültürünü çeşitli dernek ve birlikler vasıtasıyla yaymaya başladılar. $^{26}$ Bununla beraber, Atina Üniversitesi'nin verdiği burslarla

ve Littlefield, Totowa, New Jersey, 1976, s. 43-55; Steven Runciman, The Great Church in Captivity, Cambridge University Press, Cambridge, 1968, s. 165; Apostolos E. Vacalopoulos, The Greek Nation, 1453-1669, çev. Ian ve Phania Moles, Rutgers University Press, New Jersey, 1976, s. 100-150. İstanbul Rum Ortodoks Patrikhanesinin Yunan Ayaklanmasına karşı çıkmasının temel nedeni Yunan Aydınlanması ile birlikte Avrupa'daki modern ve laik eğitim sisteminin Yunanlı gençler ve Aydınlar arasında tercih ediliyor olması ve yine Avrupa'da olduğu gibi kilisenin otoritesinin sorgulanmasından kaynaklanmaktaydı. Patrikhane'nin Yunan Aydınlanmasına karşı olduğu 1798'de yayımlanan Pederler ÖğretisiPatriki Didaskalia adlı eserde görülmektedir. Pederler Öğretisi Ortodoks Rum Patrikhane'sinin neden Aydınlanma akımına karşı olduğunu ve neden Osmanlı yönetimi altında kalınması gerektiğini ele almaktadır. Konuya ilişkin daha fazla detay için bkz., Millas, a.g.e., s. 133-140. Ayrıca bir görüşe göre, İstanbul Rum Ortodoks Patrikhanesi milliyetçilik akımına iki nedenle karşı çıkmaktaydı: a) Milliyetçilik Batı kökenli bir ideolojiydi; Roma/Papalık ile İstanbul/Patrikhane arasında uzun yıllardır devam eden anlaşmazlık nedeniyle Batı'dan gelen her görüşe şüpheci bir tutum izlenmekteydi; b) Milliyetçilik laiklik ve din karşıtı olarak algılanmaktaydı. Ortodoks Rum Patrikhanesi için Helenizm'in tekrar canlanması Ortodoksluk karşıtı bir geleneğin canlanması dışında başka bir anlam taşımıyordu ve farklı ulusal kimlik düşüncesi Ortodoks Hıristiyanlığın değerlerini yıkmaktaydı. Bkz., Keith R. Legg ve John M. Roberts, Modern Greece A Civilization on the Periphery, Westview Yayınları, Oxford, 1997, s. 14-15.

${ }^{24}$ Yunanistan Kilisesi'nin İstanbul Rum Ortodoks Patrikhanesinin icazetini almadan otosefal ilan edilmesi iki dini kurum arasındaki farklılı̆̆1 göstermektedir. Kitromilides, İstanbul Rum Ortodoks Patrikhanesi’nin aksine Yunanistan Kilisesi’nin 19. ve 20. yüzy1llarda siyasi konularla daha ilgili olduğunu ve resmi devlet ideolojisinin ve Yunan milliyetçiliğinin gelişiminde önemli bir rol oynadığını belirtmektedir. Bkz., Paschalis M. Kitromilides, “"Noeres koinotites» kai oi aparhes tou ethnikou zitimatos sta Valkania”, Ethniki Taftotita kai Ethnikismos sti Neoteri Ellada, Thanos Veremis (der.), MIET, Atina, 1999, s. 82-84. Legg ve Roberts, a.g.e., s. 20.

${ }^{25}$ Kitromilides, Imagined Communities and the Origins of the National Question in the Balkans", s. 166-167.

${ }^{26}$ Legg ve Roberts, a.g.e., s. 20. 
Yunanistan dışındaki topraklarda yaşayan Yunanlılar için de eğitim olanakları sağlandı.

Çağdaş Yunan kimliğinin yaratılmasında en önemli gelişme tarihin "Helenleştirilmesi-Yunanlılaştırılması" ile gerçekleşti. "Tarihin

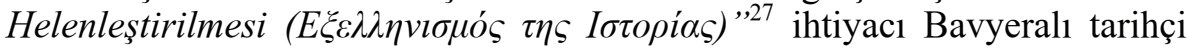
Jacob Philipp Fallmerayer'in, Bizans döneminden bu yana meydana gelen göçler nedeniyle o dönemin Yunanistan'ında ve genellikle Güney Balkanlar'da artık Yunanlı bulunmadığını, halkın tümünün Slav ırkından ve Arnavutlardan oluştuğu tezini ortaya atmasıyla önem kazanmıştır. ${ }^{28}$ Fallmerayer'ın tezi, Yunanlıların etnik kökeninin sorgulanmasına ve Avrupa'da Helenseverliğin azalmasına neden olmuşsa da, ${ }^{29}$ aynı zamanda Yunanistan'da tarihin yeniden yazılması ve Yunanlılaştırılması için de itici güç olmuştur.

Fallmerayer'in tezine cevap vermek ve tersini ispatlamak için üç paralel yol izlendi. En önemli görev tarihçilere düşmekteydi. Çünkü öncelikle Antik Yunan'dan Çağdaş Yunan Devleti'ne kadar tarihin sürekliliğinin sağlanması gerekiyordu. ${ }^{30}$ İkinci görev, çağdaş dönemde geçmiş çağların kuşku bırakmayan kanıtlarını (müzikte, örf ve adetlerde, halk şiirinde vb.) arayıp kaydederek, Yunanlılığın engelsiz devamlılığını ve dünün bugünle "gizemli" bağlarının varlığını kanıtlayacak halk bilimcilerine düşüyordu. Üçüncü görev ise, 1821 Ayaklanmasının vurgulanması ve yeniden doğuşun gerçek ispatı olarak ortaya çıkarılmasıydı. Böylelikle, ayaklanmaya katılanların kendilerini (hayali ve var olmayan değil) canlı ve var olan bir halk, yani Yunanlı olarak nitelendirmiş olmaları, Helenseverlerin bu savaşa gönüllü olarak katılmalarının da gösterdiği gibi özgürlükleri ve milli egemenlikleri uğruna savaştıklarının ispatı olarak görüldü. ${ }^{31}$

"Tarihin Helenleştirilmesi" ve tarih içinde Yunan ulusunun sürekliliğinin sağlanması aşamasında ön plana çıkan iki isim, Spiridon Zambelios $^{32}$ ve Konstantinos Paparigopulos'tu. ${ }^{33} \mathrm{Bu}$ süreçte tarihçileri

${ }^{27} \mathrm{Bu}$ terim Skopetea tarafindan kullanılmaktadır, bkz, Skopetea, a.g.e., s. 175.

${ }^{28}$ Fallmerayer'in söz konusu çalışması için bkz., Jacop Phillip Fallmerayer, Peri tis Katagogis ton Simerinon Ellinon, Yunancaya çeviren Konstantinos P. Romanos, Atina, Nefeli Yayınları, Atina, 1984. Ayrıca bkz., Gourgouris, a.g.e., s. 141; Skopetea, a.g.e., s. 171.

${ }^{29}$ Gourgouris, a.g.e., s. 142.

${ }^{30}$ Gourgouris, a.g.e., s. 49.

${ }^{31}$ Skopetea, a.g.e., s. 171-216.

${ }^{32}$ Spiridon Zambelios ve çalışmaları hakkında detaylı bilgi için bkz.,Karathanasis, a.g.e., s. $62-73$.

${ }^{33}$ Konstantinos Paparigopoulos'un eserleri ve biyografisi hakkında detaylı bilgi için bkz., Karathanasis, a.g.e., s. 37-61; Dimaras, a.g.e., s. 391-410; Svoronos, a.g.e., s. 65; Kitromilides, "On the intellectual content of Greek nationalism: Paparrigopoulos, Byzantium 
meşgul eden en önemli sorun Bizans'tı. Çünkü Yunan Ayaklanması döneminde Yunanlı aydın ve düşünürlere göre "Bizans Ortaçağın yükü̈"34 olarak algılanmaktaydı ve Bizans konusunda fazla bilgiye sahip değillerdi. Paparigopulos ilk başta Bizans'ın Yunan ulusunun tarihine dahil edilmemesini önermişti. ${ }^{35}$ Fakat Avrupa'da romantizm akımının Ortaçağa 1lımlı yaklaşımı, hatta Bizans'1 övmesi, Paparigopulos ve Zambelios'un çalışmalarında Bizans'ın da Yunan tarihinin bir parçası olduğunu ifade etmelerine yardımcı olmuş ve dolayısıyla Yunan ulusunun tarih içindeki sürekliliği sağlanmıştır. Bundan sonra Antik Yunan medeniyetinden başlayan sürecin Makedonya Helenizm'i, Bizans Helenizm'i (Ortaçağ) ve son dönem Helenizm'i ile devam ettiği kabul edildi ve Bizans tarihi ile barış sağlandı. ${ }^{36}$ Öte yandan, Bizans tarihi ile sağlanan barış Yunan Aydınlanmasının da sonu anlamına gelmekteydi. ${ }^{37}$ Çünkü yukarıda da belirtildiği gibi Yunan Aydınlanma düşüncesinde Bizans İmparatorluğu’na yaklaşım olumsuzdu ve hatta Bizans geçmişi sahiplenilmemeliydi.

Ulusal kimlik ve ulusal devlet yaratma çabalarının devam ettiği bu dönemde genel olarak Yunanistan'a baktığımızda, modern kurumların geleneksel topluma eklemlenmesinde sorunlar yaşandığını söylememiz

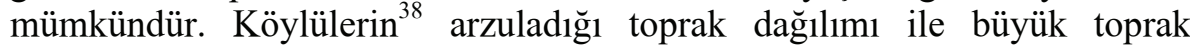
sahiplerinin bu toprak dağılımına karşı çıkması devam etmekteydi. Büyük

and the Great Idea”, s. 25-33. Paparigopulos daha sonraki dönemlerde, ilk başta karş1 olduğu Bizans'1 Yunan ulusu için en önemli süreç olarak kabul eder; çünkü o dönemde Yunanlılar ilk kez bir devlet çatısı altında birleşmeyi başarmışlardı. 1815'te İstanbul'da doğan Paparigopulos, Yunan Ayaklanması sırasında ailesinin katledilişini görmüş, bu travmanın etkisini hayatı boyunca hissetmesi beş ciltlik Yunan Ulusunun Tarihi (İstoria tou Ellinikou Ethnous) başlıklı çalışmasını hayata geçirmesinde itici güç olmuştur.

${ }^{34}$ Millas, a.g.e., s. 159-162.

${ }^{35}$ Kitromilides, "On the intellectual content of Greek nationalism: Paparrigopoulos, Byzantium and the Great Idea", s. 27.

${ }^{36}$ Böylelikle Yunan ulusunun inşasındaki mit oluşmuştur bkz., Anthony D. Smith, Ulusların Etnik Kökeni, çev. Sonay Bayramoğlu ve Hülya Kendir, Dost Kitabevi Yayınları, Ankara, 2002, s. 258-259.

${ }^{37}$ Paschalis M. Kitromilides, "Idelogika reumata kai politika aitimata: prooptikes apo ton elliniko 190 aiona", Opseis tis Ellinikis Koinonias tou 19ou Aiona, D. G. Tsaousis (der.), 2. Bask1, Estia Yayınları, Atina, 1998, s. 32.

${ }^{38}$ Bir araştırmaciya göre, Yunan toplumunun çoğunluğunu oluşturan köylüler, Osmanlı idaresinin çöküşünden kaynaklanan ekonomik güçlüklerden zor durumda kalmamış olsalardı ve Yunanlı büyük toprak sahiplerinin yaratmış olduğu toprak oligarşisinden şikayetçi olmasalard1, Yunan Aydınlanma fikirlerini benimsemeleri ve ayaklanmaya destek vermeleri çok zor olurdu. Bkz. V. Philias, "Koinonikes domes stin Ellada tou 19ou aiona”, Opseis tis Elliniiēs Koinonias tou 19ou Aiona, D. G. Tsaousis (der.), 2. Baskı, Estia Yayınları, Atina, s. $12-13$. 
toprak sahipleri, yeni devlet yapısı içerisinde siyasi ve ekonomik çıkarlarını devlet bürokrasisinde yer alarak ve ülkede yeni oluşmakta olan burjuva sınıfına dönüşerek korumayı başarmışlardı. Ülkede toprak reformunun gerçekleştiği 1870'e kadar yeterli ekonomik gelişme sağlanamamış ve halkın yaşam koşulları iyileştirilememişti. Ayrıca ülke sınırlarının darlığından şikâyet edenlerin sayısı da gün geçtikçe artmaktaydı. Bu dönemde yönetimden memnun olmayanlar ise daha iyi hayat şartları elde etmek için özellikle Osmanlı topraklarında bulunan İskenderiye ve İzmir gibi kentlere göç etmekteydi. ${ }^{39}$

Yunanistan'ın ekonomik durumunun dış desteklere rağmen düzelmemesi, yönetimin uyguladığı ağır vergi yükü, bağımsızlık savaşı sırasında aktif görev alanların yeni devlet yapısında tatmin edici görev üstlenememeleri gibi sorunlar nedeniyle, Kral Otto'ya karşı hoşnutsuzluk gün geçtikçe artırıyordu. Ayrıca 1830'larda, Kitromolides'in yorumuna göre, Yunanistan Ortodoks Kilisesinin otosefal ilan edilmesiyle, Aydinlanmanın liberal yaklaşımlarının tersine yeniden din çizgisine bir dönüş yaşanmaktaydı. ${ }^{40} \mathrm{Kral}^{\prime} ı n$ izlediği politikalardan rahatsız olan sadece Yunan halk1 değildi, aynı zamanda ayaklanma sırasında kurulan siyasi partilerin temsil ettiği Büyük Devletler de bu durumdan rahatsızdı ve Yunanistan, uzun yıllar devam edecek siyasi çekişme ve tartışmalar sürecine girmişti. ${ }^{41}$

\section{Megali İdea Peşinde Bir Ulus-Devlet}

Her ulusun geleneğinde olduğu gibi Yunan ulusunun geleneğinde de tarih süreci zincirinde boş halkalar yoktur. ${ }^{42}$ Helenizm'in tarih boyunca

\footnotetext{
${ }^{39}$ Philias, a.g.m.,s. 16-17.

${ }^{40}$ Kitromilides, "Idelogika reumata kai politika aitimata: prooptikes apo ton elliniko 190 aiona", s. 30.

${ }^{41}$ Örneğin Rus Partisi Ortodoks Yunanistan Kilisesinin otosefal ilan edilmesinden ve Patrikhane ile ilişkilerin kötü olmasından rahatsızlık duymaktaydı ve yandaşları din (Ortodoksluk) olgusunun Yunan toplumunda yeniden yükselişini destekliyorlardı. Kral Otto Katolik'ti ve Ortodoks olmaya bir türlü yanaşmaması Ortodoks Yunan toplumu için bir rahatsızlık nedeniydi. Yunanistan'da askeri darbeler serisinin ilki de bu dönemde, 3 Eylül 1843 'te yaşanmıştır. Halkın desteğini, askerlerin ve politikacıların isteklerini yerine getireceğine söz veren Kral, 1844'te yürürlüğe giren anayasayı kabul etmiş görünse de, dönemin başbakanı Kolettis ile işbirliği yaparak bir çeşit parlamenter sisteme dayalı diktatörlük kurmayı başarmıştır. Yunanistan'da bu süreçte yaşanan iç siyasi gelişmeler hakkında detaylı bilgi için bkz., Clogg, a.g.e., s. 70-80; Legg ve Roberts, a.g.e., s. 28-32; Svoronos, a.g.e., s. 81-82; Douglas Dakin, İ Enopoiisi tis Elladas 1770-1923 ( The Unification of Greece 1770-1923), İngilizce'den Yunanca'ya çeviren A. Ksanthopoulos, 5. Bask1, MIET, Atina, 2001, s. 129-132.

${ }^{42}$ Zakythinos, a.g.e., s. 150.
} 
sürekliliğinin sağlanması Megali İdea'ya da resmen bilimsel bir platform olușturmuștu. Megali İdea, resmi olarak 14 Ocak 1844'te Yunanistan Başbakanı İoannis Kolettis'in Yunan meclisinde yaptığ1 bir konuşma sırasında dile getirilmişti. ${ }^{43}$ Kolettis, "Yunanistan' in (Yunan Bizans'in) çöküşü ile Batı'nın Aydınlanma sürecinin başladığını, şimdiyse yeniden ortaya çıkışı ile hedefinin Doğu'yu Helenleştirerek uygarlaştırmak olduğunu" savunmuş ve "Yunanistan krallığının sadece Yunanistan değil, onun küçük yoksul bir parçası olduğunu" söylemişti. ${ }^{44}$ Böylelikle Megali İdea 1922'ye kadar tüm Yunanların (özellikle Osmanlı topraklarında yaşayanların) içinde bulunacağı Büyük Yunanistan'ın kurulması hayalinin açık bir ifadesi olarak Yunan ulusunun varoluş sebebi oldu ve aynı zamanda bu tarihe kadar ve sonrasında da Yunanlı siyasetçiler için bir politika malzemesi olarak kaldı. ${ }^{45}$

Çağdaş Yunan tarihçiliği Megali İdea'nın dillendirilmesi konusunda her ne kadar 1844'ü referans gösterse de, bu söylem fikir bağlamında çok daha eskilere dayandırılmaktadır. Bu düşünceyi savunanlara göre Megali İdea fikrinin kökeni; Bizans İmparatorluğu'nun 1071 Malazgirt Savaşı sonunda Anadolu'da yenilgiye uğraması, 1204 tarihinde IV. Haçlı Seferi orduları tarafindan İstanbul'un yağmalanmas1, yine İstanbul'un 1453'te Osmanlı orduları tarafindan fethi ve hatta 1461 'de Trabzon'un düşmesi ile aynı tarihi süreçte değerlendirilmelidir. ${ }^{46}$ Yani Megali İdea nihai hedef olarak Yakın Doğu'daki tüm Yunan yerleşim bölgelerini tek bir devlet altında toplayıp coğrafi olarak genişlemeyi hedefliyordu. ${ }^{47}$ Dolayısıyla Megali İdea fikri

\footnotetext{
${ }^{43}$ Karathanasis, a.g.e., s. 42.

${ }^{44}$ Aleksis İraklidis, İ Ellada kai o «eks anatolon kindinos», Polis Yayınları, Atina, 2001, s. 63.

${ }^{45}$ Yunan milliyetçiliğinin en güzel örneği olan Megali İdea benzeri düşünceler bu dönemde sadece Yunanistan’ı değil aynı zamanda tüm Balkan uluslarını etkisi altına almıştı. Aynı dönemde Sırbistan'ın "Büyük Sırbistan” düşüncesi için bkz. Skopetea, a.g.e., s. 361461. Genel olarak Balkanlar için bkz., Georges Castellan, Balkanların Tarihi (14.-20. Yüzyıl), çev. Ayşegül Yaraman-Başbuğu, 2. Bask1, Milliyet Yayınları, İstanbul, 1995; Robert D. Kaplan, Balkanlarda Kaynayan Kazan (Tarihin İçinde Yolculuk), çev. Dilek Şendil, Yayınevi Yayıncılık, İstanbul, 1995. Ayrıca, İtalya'nın birleşmesi ve bu birleşmenin Yunanistan'ın Büyük Ülkü ideolojisine etkileri için bkz. Antonis Liakos, İ İtaliki Enopoiisi kai i Megali İdea, Themelio Yayınları, Selanik, 1985. Yunanlı tarihçilere göre 1922 Küçük Asya felaketi ile sona eren Megali İdea, Yunan dış politikasından bu tarihten itibaren resmen çıkmıştır.

${ }^{46}$ Kitromilides, "Idelogika reumata kai politika aitimata: prooptikes apo ton elliniko 190 aiona", s. 25; ve aynı sayfadaki dipnot 1 ve 2; Zakythinos, a.g.e.,s. 192; Karathanasis, a.g.e., s. $43-44$.

${ }^{47}$ Tayfur, a.g.m., s. 23.
} 
1844'te Yunan parlamentosunda ifade edilene kadar çeşitli aşamalardan geçerek resmiyet kazanmıştır.

Öte yandan Elli Skopetea 19. yüzyılda Yunanistan'daki ve uluslararas1 ortamdaki siyasi gelişmeler 1şı̆̆ında, Megali İdea'nın üç farklı şekilde yorumlandığını dile getirmektedir. ${ }^{48}$ Skopetea, 1844 y1lından 1856 'ya kadar Megali İdea'nın yorumlanmasında ulusal merkezin İstanbul kabul edildiği ve temel hedefin Yunan ya da Doğu İmparatorluğu olduğunu vurgulamaktadır. ${ }^{49} \mathrm{Bu}$ tarihten sonra Megali İdea bağlamında, özellikle Yedi Adalar'ın Yunanistan topraklarına dahil olması ile birlikte, ulusal merkez olarak Atina'nın kabul edildiği ve hedefin Yunanistan sınırlarının genişlemesi olduğunu söylemektedir. ${ }^{50} 1870$ 'lere gelindiğinde ise, Megali İdea'nın bir Helen-Osmanlı İmparatorluğu şeklinde yorumlandığını belirtmektedir. ${ }^{51}$

Yukarıda Yunanlı akademisyen Skopetea'nın Megali İdea'yının dönemsel değişim ve dönüşümlerinin ilki dikkate alındığında, 1850'lerden itibaren Avrupa'da yaygınlaşmaya başlayan romantik milliyetçilik ve Yunanistan Krallığı'nın daha önce belirtilen sıkıntıları (ekonomik sorunlar, işsizlik, dış borç, toprak dağılımının bir türlü gerçekleşmemesi, yeni devletin sınırlarının Yunanlıları memnun etmemesi -özellikle Tesalya ve Girit adasının Yunanistan sınırları dışında kalması) ile birlikte, Megali idea'nın amacının yön değiştirdiğini söylemek mümkündür. Bu yön değişikliğindeki asıl amaç, Yunan toplumunu bir arada tutmak, halkın dikkatini artan iç politika sorunlarından dış politikaya yönlendirmek ve yeni devlet içinde ulusal birliğin sağlanması olarak belirtilebilir. ${ }^{52}$

Yunanistan'da ortaya çıkan kaos ortamı, ülkenin iç siyasetinde de belirli değişimlerin yaşanmasına neden oldu. Otto, Yunanistan Kralı olarak 1862'ye kadar ülkeyi yönetti. Fakat Yunanistan içinde ve dışında yönetiminden kaynaklanan rahatsızlı, ülkede yeni bir darbeye neden oldu ve yine Büyük Devletlerin seçtiği Danimarka Prensi William 1864'te Kral I. Yorgos adını alarak ülkenin başına geçti. ${ }^{53}$ Aynı yıl Yunanistan'da, 1844 Anayasası'yla getirilen demokratik özgürlükler biraz daha genişletilerek, yeni bir anayasa kabul edildi. Yunanistan'ın bağımsızlık savaşından sonra gerçekleşen ilk sınır genişlemesi İyon denizindeki İyon adalarının

\footnotetext{
${ }^{48}$ Skopetea, a.g.e., s. 269.

${ }^{49}$ Skopetea, a.g.e., s. 273-286.

${ }^{50}$ Skopetea, a.g.e., s. 287-307.

${ }^{51}$ Skopetea, a.g.e., s. 308-324.

${ }^{52}$ Kitromilides, "Imagined Communities and the Origins of the National Question in the Balkans", s. 165.

${ }^{53}$ Dakin, a.g.e., s. 146.
} 
Yunanistan'a dahil edilmesi ile gerçekleşti. ${ }^{54}$ Megali İdea artık ülke içinde gün geçtikçe daha çok heyecan uyandırmaya başlamıştı. Çünkü Megali İdea'nın bu tarihlerde yorumlanmasında da değişiklik yaşanmıştı. Artık ulusal merkez Atina kabul edilmekte ve temel hedef ülkenin coğrafi sınırlarının genişlemesidir ${ }^{55}$.

19. yüzyılın sonlarına (1870'ler) gelindiğinde Yunanistan'da "Modernleşmeci-Trikupis ve gelenekselci-Deliyannis" ${ }^{56}$ çizgisinde iki partili bir sistemin oluştuğu görülmektedir. ${ }^{57} \mathrm{Bu}$ iki siyaset adamı arasında iktidar, dönüşümlü olarak yirminci yüzyılın başlarına kadar el değiştirmiş ve ulusal bölünme süreci bu dönemde hissedilmeye başlamıştır. ${ }^{58}$ Aynı tarihlerde yaşanan diğer iki önemli gelişme de toprak reformunun gerçekleşmesi ve Berlin Kongresi (1878) sonucunda Tesalya bölgesinin Yunanistan sinırları içine alınması (ikinci kez genişlemesi) ile ilgilidir. ${ }^{59}$ Skopetea'nın savına göre, bu dönem itibarıyla Megali İdea bir Helen-Osmanlı İmparatorluğu şeklinde yorumlanmalıdır. İstanbullu Rum aydınların, Atina ve Yunanistan sınırları içerisinde yaşayan Yunanlılarla çok yakın akrabalık ilişkileri olsa da onlardan çok farklı bir konumda bulunmaktaydılar. Fenerli Rumlar, özellikle bu dönemde Osmanlı İmparatorluğu'nun önemli yönetsel ve idari pozisyonlarında yer almaktaydılar ve Atina'ya kıyasla "esaret" altındaki Helenleri daha etkin bir şekilde etkileme imkânına sahiptiler. Dolayısıyla Atina merkezli Megali İdea'ya İstanbul merkezli "soydaşları" cevabı Osmanlı İmparatorluğunun sinırlarının korunması, reformların gerçekleştirileceği ve yaşayacağı bir Helen-Osmanlı imparatorluğunun kurulması şeklinde olmuştur. ${ }^{60}$

Tüm bu gelişmelere rağmen ülkenin yüksek miktardaki dış borçları ve yanlış ekonomik politika uygulamaları nedeniyle 1893'te Başbakan Trikoupis devletin iflas kararını açıklamak zorunda kalmış ve dönemin Büyük Güçleri’nin de baskısıyla Yunanistan'da uluslararası bir denetleme

${ }^{54}$ Dakin, a.g.e., s. 158. Clogg bu adaların İngiltere tarafindan Yunanistan'a verilmesi konusunda "yayılmacı tutkuları hafifletmek için, İngiltere bir nevi çeyiz olarak İyon adalarını Yunanistan'a" bıraktı yorumunu yapmaktadır. Bkz., Clogg, a.g.e., s. 80.

${ }^{55}$ Skopetea, a.g.e., s. 293.

${ }^{56} 1875$ 'te Kral'ın parlamentoda çoğunluğu elde eden parti liderinin hükümeti kurma yetkisini kabul etmesiyle iki partili bir sistem oluşmuştur.

57 1850'lerden itibaren İngiliz, Fransız ve Rus partilerine dayalı eski siyasal gruplaşmalar Megali İdea fikri ile ortadan kalkmaya başlamıştır. Clogg, a.g.e., s. 73.

${ }^{58}$ Trikupis önce devletin modernleşmesi ve kurumlarının sağlamlaşmasını, daha sonra Megali İdea fikrinin gerçekleşmesi için girişimlerde bulunulmasını destekliyordu; Deliyannis ise, halkçı bir söylem benimseyerek Megali İdea'yı ateşli bir şekilde savunuyordu.

${ }^{59}$ Legg ve Roberts, a.g.e., s. 32.

${ }^{60}$ Skopetea, a.g.e., s. 310-311. 
kurulu oluşturulmuştur. ${ }^{61}$ Yunanistan'da ekonomik anlamda yaşanan sorunlar bu tarihlerde özellikle $\mathrm{ABD}$ ve Avustralya'ya yönelik göçe de neden olmuştur. Öte yandan bu göçler sayesinde Yunan ekonomisine bir hareketlilik gelmiştir. Yurtdışındaki işçilerden gelen sermaye sadece ülke ekonomisine canlılık katmakla kalmamış, yurtdışında diaspora gücünün oluşmasına da katkı sağlamıştır ${ }^{62}$.

Yukarıda ifade edilen coğrafi genişlemeler Yunanistan için yeterli olmadı. Girit ${ }^{63}$ adasının Yunanistan sınırları dışında kalması, adada çeşitli tarihlerde ayaklanmalar çıkmasına ve Osmanlı İmparatorluğu ile Yunanistan arasındaki ilişkilerin gerginleşmesiyle Büyük Devletlerin müdahalesine neden oldu. Yunan Hükümeti 1897'de Girit'e tekrar asker gönderdiği sırada Yunan ordusu Osmanlı ordularına Tesalya civarında mağlup oldu. $\mathrm{Bu}$ mağlubiyet aslında Megali İdea fikrinin kolay gerçekleşecek bir amaç olmadığını göstermekteydi.

1892'de özerkliğini kazanmış olsa da bir türlü Yunanistan sınırlarına dahil olamayan Girit ve bununla beraber Yunanistan'da ekonomik problemlerin tam olarak giderilememiş olması neticesinde, ülkede siyasetçilere yönelik güvensizlik de arttı. Bu güvensizlik sonucunda 1909'da Goudi Darbesi ${ }^{64}$ olarak bilinen askeri müdahale gerçekleşti. Ayaklanmalar ve ekonomik sıkıntıların zemin hazırladığı Goudi Darbesi, Yunanistan'ın özelinde yeni bir siyaset adamı üretti. Cunta yöneticileri ülkenin yönetimini teslim etmek için halkın gözünde olumlu imaja sahip ve eski siyasetçilerle bağlantısı olmayan Elefterios Venizelos'u seçtiler. Böylelikle Megali İdea fikrini gerçekleştirme teşebbüsünde bulunarak Yunanistan siyasi tarihine damgasını vuracak olan Elefterios Venizelos Aralık 1910'da yapılan seçimlerle iktidara geldi. ${ }^{65}$

${ }^{61}$ Kral I. Yorgos döneminde ülkenin en büyük sorunlarından birisi ekonomik azgelişmişlikti. Dolayısıyla devlet memuriyetinde büyük bir yığılma vardı ve bu dönemde tarım toplumu olan Yunanistan'ın memur sayısı sanayileşmiş İngiltere'den yedi kat daha fazlaydi. Legg ve Roberts, a.g.e., s. 34 .

${ }^{62}$ Legg ve Roberts, a.g.e., s. 34.

${ }^{63}$ Girit sorunu için bkz. Armaoğlu, a.g.e., s. 555-563.

${ }^{64}$ Goudi Darbesini oluşturan şartlar için bkz., Svoronos, a.g.e., s. 110.

${ }^{65}$ Eski siyasetçilere duyulan güvensizliği göz önünde bulunduran Goudi darbecileri, ülkeyi zor durumdan çıkarması için Girit meselesinde önemli bir konuma sahip olan Elefterios Venizelos'u tercih etmişlerdir. 1910'da gerçekleşen anayasa reformu ve seçimler sonucunda Venizelos'un Liberal Partisi (Komma Fileleftheron) iktidara geldi. Clogg, a.g.e., s. 97. 


\section{Megali İdea Peşinde Yeni Bir Lider}

Uyguladığı 1lımlı politikalarla farklı grupların desteğini kazanan Venizelos, Yunanistan içinde birlik anlayışının oluşmasını sağladı. Fakat, Girit kökenli Venizelos iktidara geldikten kısa bir süre sonra Balkanlarda Makedonya sorunu yeniden gündeme geldi. 19. yüzyılının sonunda Osmanlı İmparatorluğu'ndan bağımsızlıklarını kazanan bölge ülkeleri için bu toprak parçası, Balkan Savaşları ${ }^{66}$ ile bir çekişme sahası oldu. Balkan Savaşları'nın sonucunda Yunanistan'ın sınırları üçüncü kez genişledi ve ülkenin nüfusu iki katına çıktı. ${ }^{67}$

Birinci Dünya Savaşı'na giden süreçte Yunanistan'da “Ulusal Bölünme" olarak adlandırılan olgu da yavaş yavaş gündeme gelmeye bașlamıștı. Ülkenin ideolojik olarak iki kampa bölünmesinin temel nedeni Venizelos ile Kral Konstantinos ${ }^{68}$ arasında Birinci Dünya Savaşı'na katılıp katılmama konusunda yaşanan fikir ayrılığıydı. Venizelos, İtilaf Güçleri ile savaşa girmeyi ve bu sayede Megali İdea'yı gerçekleştirmeyi umuyordu. Kral ise, eşinin Alman İmparatoru II. Wilhem'in kız kardeşi olmasının da etkisiyle, İttifak Güçleri’nin yanında yer alınması görüşünü savunmaktaydı. Öte yandan Kral, İtilaf devletlerinin askeri gücünü bildiği için Yunanistan'ın bu savaşta İttifak Güçleri'nin yanında yer almaması durumunda tarafsız kalmasının daha uygun olacağını düşünmekteydi. Kral Konstantinos ile Venizelos arasındaki anlaşmazlık kısa sürede halka da yansıdı ve Birinci Dünya Savaşı arifesinde Yunanistan siyasi krize girdi.

Kral taraftarları Yunanistan'ın bu savaşta tarafsız kalması ve Megali İdea'yı gerçekleştirmek için önce iktisadi kalkınmanın sağlanması gerektiği görüşündeydiler. Venizelos ve taraftarları ise Osmanlı İmparatorluğu'nun parçalanma planlarında yer almak istiyordu. Osmanlı İmparatorluğu'na saldırarak antik Yunan toprakları sayılan toprakları ele geçirmeyi ve esaret altında kalan tüm Yunanlıları bir devlet çatısı altında toplamayı, kısaca Megali İdea'yı gerçekleştirme görüşünü savunuyorlard $1 .{ }^{69}$

Giderek keskinleşen fikir ayrılığı sonucunda Venizelos, İtilaf Güçleri'nin (özellikle İngiltere) desteği ile Ekim 1916'da Selanik'te geçici bir hükümet kurdu. Bu fikir ayrılığı sonucunda Yunanistan'da iki başlı bir yönetim ortaya çıktı. Kral Atina ve çevresinde yönetimi ele alırken,

\footnotetext{
${ }^{66}$ Balkan Savaşları, sonuç ve etkileri için bkz., Armaoğlu, a.g.e., s. 651-695.

${ }^{67}$ Svoronos, a.g.e., s. 116-118.

${ }^{68}$ Kral I. Yorgos Mart 1913'te suikast sonucu öldürülünce yerine oğlu veliaht Prens Konstantinos geçti.

${ }^{69} \mathrm{Bu}$ süreçte Yunanistan'da yaşanan siyasi krizler ve Kral Konstantinos ile Venizelos arasındaki fikir ayrılığını sonuçları için bkz., Clogg, a.g.e., s. 108-112; Gianoulopoulos, a.g.e., s. $224-248$.
} 
Venizelos nüfuz alanı olarak Selanik ve civarını seçti. İtilaf Güçleri'nin desteği ile Venizelos Haziran 1917'de Atina'ya dönerken, Kral Konstantinos tahtı ikinci oğlu Aleksandros'a bırakarak ülkeden ayrıldı. Fakat Konstantinos'un ülkeden ayrılmasına rağmen ülkedeki fikir ayrılığı (bölünme) devam etti. ${ }^{70}$ İtilaf Güçleri’nin Birinci Dünya Savaşı'ndan galip çıkmasıyla Venizelos, ülkesi galiplerin yanında yer aldığı için Osmanlı İmparatorluğu topraklarının paylaşımında mükâfatlandırılacağını düşünüyor ve Megali İdea fikrinin gerçekleşmesinin yakın olduğuna inanıyordu.

Yunanistan'ın planlarını gerçekleştirmedeki önceliği, sayısal olarak en fazla Rumun yaşadığ $\breve{1}_{1}$ Osmanlı toprağ 1 İzmir'di. Bir diğer önemli bölge ise 1913'ten beri İttifak güçleri ile Birinci Dünya Savaşı'na giren ve mağlup olan Bulgaristan'ın işgalindeki Trakya bölgesiydi. Venizelos'a göre Helenizmin bulunduğu diğer bölgeler ise Güney Arnavutluk (Yunanlilara göre Kuzey Epir) ve Oniki Adalardı. Fakat dönemin şartları göz önünde bulundurulduğunda bu bölgelerin Yunanistan sınırları kapsamına alınmasının mümkün olmayacağını da düşünüyordu. ${ }^{71}$

Mondros Silah Bırakışması'nın (30 Ekim 1918) ardından Paris Barış Konferansı'na (1919) giden Venizelos, yukarıda ifade edilen hedefleri gerçekleştirmeyi arzuluyordu. Fakat daha antlaşma imzalanmadan İtalya'nın Antalya bölgesine doğru ilerlemesi, İngiltere, Fransa ve Amerika tarafindan desteklenen Yunan ordularının 15 Mayıs 1919 'da İzmir'e çıkış sürecini hızlandırdı. ${ }^{72}$ Yunan ordularının İzmir ve civarını işgal etmesinden bir yıl sonra Osmanlı İmparatorluğu ile Müttefikler arasında imzalan Sèvres Antlaşması (10 Ağustos 1920) Yunanistan'da büyük bir coşkuyla karşılandı. Fakat aynı dönemde Türk Kurtuluş Savaşı'nın başlaması ve Yunanistan'da 14 Kasım 1920 tarihinde yapılan seçimlerde Venizelos'un oy kaybına uğrayarak Kral yanlısı Rallis'e iktidarı devretmesi ve ardından Kral Konstantinos'un ülkeye tekrar gelmesi sonucunda Müttefiklerin Yunanistan politikası da değişime uğradı. ${ }^{73}$

Yunan ordularının Anadolu'ya çıkmasına ilk aşamada karşı çıkan Kral ülkeye döndükten sonra, Megali İdea'ın gerçekleşmesini sağlayacak Anadolu harekâtına destek verdi. Türklerin beklenmedik bir şekilde mücadele etmesi ve işgale karşı direnmesi sadece Yunanlıları değil, diğer

${ }^{70}$ Kral Konstantinos taraftarlarının akıbeti için bkz., Clogg, a.g.e., s. 118.

${ }^{71}$ Legg ve Roberts, a.g.e., s. 35 .

${ }^{72}$ Clogg, a.g.e., s. 118 .

${ }^{73} \mathrm{Bu}$ seçimler sonucunda Yunanistan'daki siyasi bölünme daha da keskinleştirmiştir. Venizelos'un seçimleri kaybetmesinin en önemli nedeni halkın savaşmaktan yorulması ve ekonomik zorlukların artmasıdır. İktidara gelen Kral yanlıları ise Venizelos taraftarlarını cezalandırmaya başlamışlardır. Bu dönemdeki uygulamalar ve detaylar için bkz., Clogg, a.g.e., s. 119-121. 
güçleri de zor durumda bırakmıştır. Politikalarını gözden geçirip yeniden belirleyen İtalya ve Fransa, işgal ettikleri Osmanlı topraklarından birer birer ayrılmışlar, İngiltere ise Yunanistan'ın yenilgisine kadar bu savaştaki manevi varlığını sürdürmüştür. Sèvres Antlaşması'nın yürürlüğe girmemesi ve Büyük Güçlerin Yunanistan planının işe yaramaması sonucunda Anadolu topraklarında yalnız kalan Yunanlılar hayal kırıklığına uğramışlar ve uluslararası ortamda yalnız kalmışlardır.

Türk ordularının 26 Ağustos 1922 'de başlattı̆ğ Büyük Taarruz sonucunda 8 Eylül 1922'de İzmir'in Türkler tarafından geri alınması ve 11 Ekim 1922'de imzalanan Mudanya Silah Bırakışması ile Türk-Yunan savaşı son buldu. ${ }^{74}$ Yunanistan, Anadolu ve İzmir topraklarından çekildi ve en önemlisi Megali İdea ve Büyük Yunanistan'1 yaratma hayalinin artık gerçekleşemeyeceği gerçeği ile yüzleşti. ${ }^{75}$ Yunanlıların İzmir'den çekilirken yaşadıkları travma ${ }^{96}$ ise uzun yıllar devam etti.

$\mathrm{Bu}$ yenilginin Yunan iç siyasetinde yarattı̆̆ içindeki dengelerin değişmesine neden oldu. Yenilginin faturasını Anadolu'daki Yunan ordularının komutanları, vatana ihanet suçu ile yargılanıp idam edilerek ödedi. ${ }^{77} \mathrm{Bu}$ gelişmelerin ardından Venizelos taraftarı bazı subaylar iktidarı ele geçirince Kral Konstantinos ülkeden ayrılarak tahtı büyük oğlu Kral II. Yorgos'a birakmak zorunda kald1. ${ }^{78}$ 1923'te yapılan seçimlerde Venizelos karşıtları seçimi boykot ettiği için Venizelos ve partisi tekrar ülke yönetimini ele geçirdiler. Yine de 1928'de yapılacak seçimlere kadar Yunanistan General Pangalos liderliğindeki askeri yönetim tarafından idare edildi. ${ }^{79}$ İki dünya savaşı arası dönemde Yunanistan'da devam eden siyasi istikrarsızlık ve ulusal bölünme

${ }^{74}$ Salahi R. Sonyel, Türk Kurtuluş Savaşı ve Dış Politika, Cilt I, Türk Tarih Kurumu Yayınları, Ankara, 1973 ve Baskın Oran, "1919-1923 Mudanya Silah Bırakışması”, Türk Dış Politikası, Kurtuluş Savaşından Bugüne Olgular, Belgeler, Yorumlar, Baskın Oran (der..), Cilt I, İstanbul, İletişim Yayınları, 2001, s. 213-214.

75 Yunanistan'da Batı Anadolu'da yaşananlar Küçük Asya Felaketi (Mikrasiatiki Katastrofi), bu topraklar da Kaybedilmiş Topraklar (Hamenes Patrides) olarak adlandırılmaktadır.

${ }^{76}$ Vamık D. Volkan ve Norman Itzkowitz, Türkler ve Yunanlılar, Çatışan Komşular, Bağlam Yayıncılık, İstanbul, 2002, s.228.

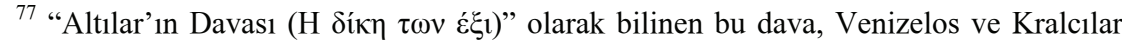
arasındaki fikir ayrılığının daha da yoğunlaşmasının ve İkinci Dünya Savaşına giden süreçte Yunanistan'da yaşanan siyasi krizlerin başlangıcı olmuştur. Clogg, a.g.e., s. 99.

${ }^{78}$ Legg ve Roberts, a.g.e., s. 36. Kral II. Yorgos Arallk 1923'te Yunanistan'dan ayrılmak zorunda kalmış ve bir yıl sonra yapılan halkoylaması sonucunda Yunanistan'da monarşi kaldırılmıştır.

${ }^{79} \mathrm{Bu}$ dönemde yaşanlar için bkz., Clogg, a.g.e., s. 106. 
çerçevesinde partiler bazen ordu ile işbirliği yaptılar, bazen de orduya karşı çıktılar. Fakat, siyasiler arasında yaşanan fikir ayrılıkları Yunan ordusunu, siyasetin kaçınılmaz bir parçası haline getirdi. ${ }^{80}$

\section{SONUC}

Bağımsızlı̆̆ın kazanıldığı ilk yıllarda dönemin Büyük Güçlerinin yardımına ve desteğine her an ihtiyacı olan Yunanistan, ülke içinde birliği sağlamayı becerebilecek ve tek başına ayakta durabilecek bir devlet olamadı. Fakat kendilerini modern dünyanın temelini oluşturan medeniyetin temsilcileri olarak kabul eden ve dolayısıyla dünyanın, atalarından dolayı kendilerine minnet borçlu olduğuna inanan Yunanlılara göre, genel olarak iç ve dış politikada meydana gelen olumsuz gelișmelerin sorumlusu "şanlı geçmişlerini" kıskanan ve onu ele geçirerek yok etmeye çalışan yabancılardı.

Yunanistan Osmanlı hâkimiyetinden çıkıp bağımsızlığını elde ettikten sonra ülkede ulus yaratma süreci de başladı. Tarihte yer alan mağlubiyetler (örneğin İstanbul'un Osmanlı orduları tarafından fethi) ve zaferler (yine Osmanlı İmparatorluğu'na karşı ayaklanma ve bağımsızlığın elde edilmesi), antik dönemin sahiplenilmesi, tarihin Helenleştirilmesi, başka bir deyişle yeniden yazılması gibi gelişmeler, Yunan toplumunu bir arada tutmak için yeniden yaratılmış olgular olarak tarihte yerini aldı.

Yunan ulusunu bir arada tutmak için ortaya atılan ve daha sonra hayata geçirilmeye çalışılan Megali İdea fikri de, bu hisler (Helen olma durgusu ya da dünya tarihine hükmetme duygusu) sonucunda ortaya çıkmıştır. Osmanlı İmparatorluğu ile yaşanan son savaştan sonra Megali İdea fikrinin uygulamaya konmasına ön ayak olan Venizelos, ülkesinin ulusal çıkarlarını korumak için Büyük Güçlerin çizgisinden ayrılmayarak bir politika izlemeye gayret etmiş ve Yunanistan'ın hem Akdeniz'de hem de Balkanlarda etkin bir konuma sahip olması yönünde hareket etmiştir. Çalışmamızın ikinci bölümünde de görüldüğü gibi, Venizelos ve Kral arasında yaşanan anlaşmazlık da "dönemin çatışma içindeki büyük güçlerden hangisinin

${ }^{80}$ Yunan siyasetinde ordunun etkisi için bkz., Legg ve Roberts, a.g.e., s. 37 ve ayrica George A. Kourvetaris, "The Social Structure and the Armed Forces of Greece in the Nineteenth Century, With Special Emphasis on the Greek Revolution of 1821 ", Studies on Modern Greek Society and Politics, George A. Kourvetaris (der.), New York, Columbia University Press, 1999, s. 27-60; George A. Kourvetaris, "Civil Military Relations in Greece: 1909-1974”, Studies on Modern Greek Society and Politics, George A. Kourvetaris (der.), New York, Columbia University Press, 1999, s. 61-81; George A. Kourvetaris, "The 1967 Military Coup and the Role of the Military in Greek Politics", Studies on Modern Greek Society and Politics, George A. Kourvetaris (der.), New York, Columbia University Press, 1999, s. 129-151. 
yanında yer alınmalı?" konusunda yaşanmış ve ülkeyi uzun yıllar sürecek bir siyasi bölünmeye sürüklemiştir.

Osmanlı İmparatorluğu'nun çöküşü ve topraklarının, dönemin büyük güçleri tarafından paylaşımı ile gelişen I. Dünya Savaşı, Yunan devletinin sınırlarının arzu edilen boyutlara ulaşması açısından önemli bir firsat olmuştur. Böylelikle Venizelos liderliğindeki Yunanistan, Yunanlı tarihçilerin "Büyük Bozgun" veya "Küçük Asya Felaketi" olarak adlandırdıkları bir sonla neticelenecek olan Anadolu macerasına girişmiştir. Yunanistan'ın bu yayılmacı politikası sadece Megali İdea için derin etkiler doğuracak bir darbe olmakla kalmamış, aynı zamanda ülkeyi ciddi ekonomik ve sosyal sorunlarla karşı karşıya bırakan ve Yunanlılar için İstanbul'un Osmanlı ordularınca ele geçirilmesiyle kıyaslanacak ikinci büyük travma olmuştur. Bu tarihten itibaren Megali İdea fikri resmi dış politikadan çıkmış, fakat Yunan ulusunu bir arada tutmak için akillarda daima yer alan ve gerçekleşmesi arzulanan bir olgu olarak kalmıştır. 
KAYNAKÇA

Anderson, Benedict, Hayali Cemaatler; Milliyetçiliğin Kökenleri ve Yayılması, çev. İskender Savaşır, 2. Baskı, Metis, İstanbul, 1995.

Armaoğlu, Fahir; 19. Yüzyıl Siyasi Tarihi (1789-1914), 4. Baskı, Alkım Yayınevi, İstanbul, 2007.

Castellan, Georges; Balkanların Tarihi (14.-20. Yüzyıl), çev. Ayşegül YaramanBaşbuğu, 2. Baskı, Milliyet Yayınları, İstanbul, 1995.

Clogg, Richard; A Concise History of Greece, 2. Bask1, Cambridge, 2002.

Dakin, Douglas; İ Enopoiisi tis Elladas 1770-1923 ( The Unification of Greece 1770-1923), İngilizce'den Yunanca'ya çeviren A. Ksanthopoulos, 5. Bask1, MIET, Atina, 2001.

Dimaras, H. Th.; Neoellinikos Diafotismos, 7. Bask1, Atina, 1998.

Falmerayyer, Jacop Phillip; Peri tis Katagogis ton Simerinon Ellinon, Yunancaya çeviren Konstantinos P. Romanos, Nefeli Yayınları, Atina, 1984.

Gianoulopoulos, Giannis N.; "İ evgenis mas tiflosis..." Eksoteriki Politiki kai Ethnika Themata apo tin itta tou 1897 eos ti Mikrasiatiki Katastrofi, 2. Bask1, Vivliorama Yayınları, Atina, 1999.

Glikatzi-Arveler, Eleni; İ Politiki İdeologia tis Vizantinis Aftokratorias, 4. Baskı, Psihogios Yayınları, Atina, 1992.

Guibernau, Monserrat, Nationalism; The Nation State and Nationalism in Twentieth Century, Polity Press, Cambridge, 1996.

Gourgouris, Stathis; Dream Nation, Enlightment, Colonization and the Intsitution of Modern Greece, Standford University Press, California, 1996.

Hutchinson, John ve Anhony D. Smith; (der.) Nationalism, Oxford University Press, Oxford ve New York, 1994.

İraklidis, Aleksis; İ Ellada kai o «eks anatolon kindinos», Polis Yayınları, Atina, 2001.

Jusdanis, Gregory; Gecikmiş Modernlik ve Estetik Kültür Milli Edebiyatın İcat Edilişi, çev. Tuncay Birkan, Metis Yayınları, İstanbul, 1998.

Kaplan, Robert D.; Balkanlarda Kaynayan Kazan (Tarihin İçinde Yolculuk), çev. Dilek Şendil, , Yayınevi Yayıncılık, İstanbul, 1995.

Karathanasis, E.; İ Trisimi Enotita tou Ellinismou, Archaiotita-Byzantio-Neos Ellinismos, Kiriakidi Kardeşler Yayınları, Selanik, 1991. 
Kellas, James G., The Politics of Nationalism and Ethnicity, MacMillan, Londra, 1991.

Kitromilides, Paschalis M.; "Imagined Communities and the Origins of the National Question in the Balkans”, European History Quarterly, Cilt 19, No 2, 1989, s. 149-192.

-------; "On the intellectual content of Greek nationalism: Paparrigopoulos, Byzantium and the Great Idea”, Byzantium and the Modern Greek Identity, David Ricks ve Paul Magdalino (der.), Centre for Hellenic Studies, King's College, Londra, 1998, s. 25-33.

-; “Idelogika reumata kai politika aitimata: prooptikes apo ton elliniko 190 aiona”, Opseis tis Ellinikis Koinonias tou 19ou Aiona, D. G. Tsaousis (der.), 2. Bask1, Estia Yayınları, Atina, 1998, s. 23-38.

------; “"Noeres koinotites» kai oi aparhes tou ethnikou zitimatos sta Valkania”, Ethniki Taftotita kai Ethnikismos sti Neoteri Ellada, Thanos Veremis (der.), MIET, Atina, 1999, s. 53-131.

Kourvetaris, George A.; "The Social Structure and the Armed Forces of Greece in the Nineteenth Century, With Special Emphasis on the Greek Revolution of 1821", Studies on Modern Greek Society and Politics, George A. Kourvetaris (der.), Columbia University Press, New York, 1999, s. 27-60.

------; “Civil Military Relations in Greece: 1909-1974”, Studies on Modern Greek Society and Politics, George A. Kourvetaris (der.), Columbia University Press, New York, 1999, s. 61-81.

-------; “The 1967 Military Coup and the Role of the Military in Greek Politics", Studies on Modern Greek Society and Politics, George A. Kourvetaris (der.), Columbia University Press, New York, 1999, s. 129-151.

Legg, Keith R. ve John M. Roberts; Modern Greece A Civilization on the Periphery, Westview Yayınları, Oxford, 1997.

Liakos, Antonis; İ İtaliki Enopoiisi kai i Megali İdea, Themelio Yayınları, Selanik, 1985.

Millas, Herkül; Yunan Ulusunun Doğuşu, İletişim Yayınları, İstanbul, 1994.

Oran, Baskın; Azgelişmiş Ülke Milliyetçiliği, Güncelleştirilmiş 3. Baskı, Bilgi Yayınları, Ankara, 1997.

; “1919-1923 Mudanya Silah Bırakışması”, Türk Dış Politikası, Kurtuluş Savaşından Bugüne Olgular, Belgeler, Yorumlar, Baskın Oran (der..), Cilt I, İstanbul, İletişim Yayınları, 2001, s. 213-214. 
Philias, V.; "Koinonikes domes stin Ellada tou 19ou aiona", Opseis tis Ellinikis Koinonias tou 19ou Aiona, D. G. Tsaousis (der.), 2. Baskı, Estia Yayınları, Atina, s. 11-21.

Politis, Alexis; “Christian Emperors to Greek Ancestors”, Byzantium and the Modern Greek Identity, David Ricks ve Paul Magdalino (der.), Centre for Hellenic Studies, King's College, Londra, 1998, s. 1-14.

Runciman, Steven; The Great Church in Captivity, Cambridge University Press, Cambridge, 1968.

Sander, Oral, Siyasi Tarih, Cilt I, 5. B., İmge, Ankara, 1994.

Skopetea, Elli; To Protipo Vasileio kai i Megali İdea, Opseis tou Ethnikou Provlimatos stin Ellada (1830-1880), Politipo Yayınları, Atina, 1988.

Smith, Anthony D.; Ulusların Etnik Kökeni, çev. Sonay Bayramoğlu ve Hülya Kendir, Dost Kitabevi Yayınları, Ankara, 2002.

Sonyel, Salahi R.; Türk Kurtuluş Savaşı ve Dış Politika, Cilt I, Türk Tarih Kurumu Yayınları, Ankara, 1973.

Stavrakakis, Yannis; "Religion and Populism: Reflections on the 'politicised" discourse of the Greek Church", Discussion Paper No. 7, The Hellenic Observatory, London School of Economics and Political Science, Londra, 2002, s. 1-60.

Svoronos, Nikos G.; Anelekta Neoellinikis İstorias kai İstoriografias, 3. Bask1, Themelio Yayınları, Atina, 1999.

------; Episkopisi tis Neoellinikis İstorias, Yunancaya çev. Aikaterini Asdracha, Themelio Yayınları, Atina, 1999.

Tayfur, M. Fatih; “Akdeniz'de Bir Adanın Kalın Uçlu Bir Kalemle Yazılmış Hikayesi: Kıbrıs”, Akdeniz'de Bir Ada, O. Türel (der.), İmge Yayınları, Ankara, 2002, s. 13-51.

Vacalopoulos, Apostolos E.; The Greek Nation, 1453-1669, çev. Ian ve Phania Moles, Rutgers University Press, New Jersey, 1976.

Veremis, Thanos; “Kratos kai Ethnos stin Ellada 1821-1912”, Ellinismos kai Ellinikotita, İdeologikoi kai Viomatikoi Aksones tis Neoellinikis Koinonias, D. G. Tsaousis (der.), Estia Yayınları, Atina, 1983, s. 59-67.

Volkan, Vamık D. ve Norman Itzkowitz; Türkler ve Yunanlılar, Çatışan Komşular, Bağlam Yayıncılık, İstanbul, 2002.

Zakythinos, D. A.; The Making of Modern Greece From Byzantium to Independence, Rowman ve Littlefield, Totowa, New Jersey, 1976. 